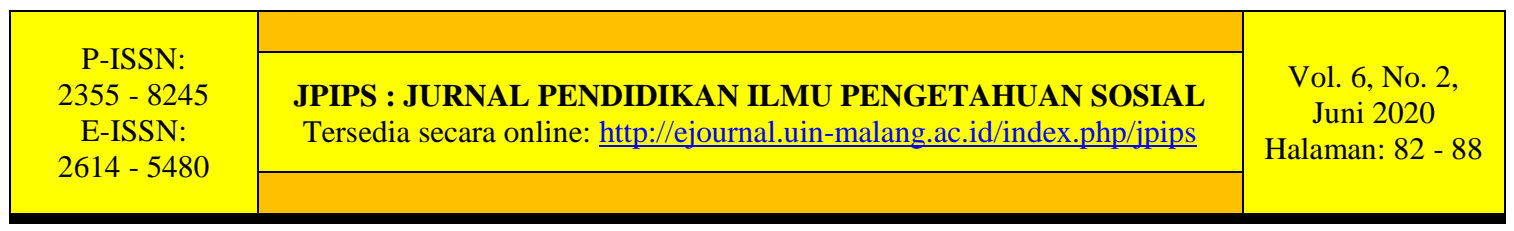

\title{
RESIKO GANGGUAN KESEHATAN PADA MASAYARAKAT SEKITAR TEMPAT PEMBUANGAN AKHIR (TPA) TALANGAGUNG KABUPATEN MALANG
}

\author{
Uswatun Hasanah $^{1}$, Amy Septiamuna ${ }^{2}$, Syaiful Rizal ${ }^{3}$, M. Imron Rusydi ${ }^{4}$ \\ ${ }^{1234}$ Universitas Islam Negeri Maulana Malik Ibrahim Malang \\ 11uswahhasanah626@gmail.com, 22septiamy@gmai.com, \\ ${ }^{3}$ rizal.syaiful@gmail.com, ${ }^{4}$ setiawanrusydi@gmail.com
}

Diterima: 21-05-2019.; Direvisi: 10-11-2019; Disetujui: 30-12-2019

Permalink/DOI: $10.15548 /$ jpips.v6i2.7004

Abstrak: Penelitian ini bertujuan untuk mengetahui resiko pada kesehatan masyarakat di TPA Talangagung. Jenis penelitian ini merupakan penelitian deskriptif kuantitatif. Populasi pada penelitian ini yaitu masyarakat yang tinggal dan bekerja di TPA Talangagung Kabupaten Malang. Instrument yang digunakan dalam penelitian ini menggunakan kuisioner yang di bagikan kepada masyarakat sekitar TPA. Analisis data menggunakan analisis deskriptif kuantitatif dengan mengumpulkan data yang didapatakan dari masyarakat, kemudian mendiskripsikan hasil data yang terkumpul apa adanya dengan menggunakan rumus presentase. Dari hasil analisis data kuisioner ada sebesar $40 \%$ gangguan pernafasan, $20 \%$ gangguan pencernaan dan $10 \%$ gangguan kulit.TPA Talangagung Kabupaten Malang dalam pelaksanaannya sudah sesuai dengan prosedur yang ditetapkan pemerintah, sehingga dampak yang di timbulkan oleh TPA Talanggung tidak ada berbau dan tidak membuat kerusakan lingkungan.

\section{Kata Kunci: kesehatan; tempat pembuangan akhir sampah}

Abstract: This study aims to determine risks to public health in the Talangagung Landfill. This type of research is a quantitative descriptive study. The population in this study is the people who live and work in TPA Talangagung, Malang Regency. The instrument used in this study used a questionnaire that was distributed to the community around the landfill site. Data analysis using quantitative descriptive analysis by collecting data obtained from the community, and then describes the results of the data collected as is by using the percentage formula. From the analysis of the questionnaire data there are $40 \%$ of respiratory disorders, $20 \%$ of digestive disorders and 10\% of skin disorders. TPA Talangagung Malang Regency in its implementation is in accordance with procedures set by the government in accordance with the Law, so that the impact caused by the Talanggung TPA has no odor and does not cause environmental damage.

Keywords: health; landfills 


\section{PENDAHULUAN}

Jumlah manusia semakin bertambah dengan berkembangnya teknologi dan ilmu pengetahuan. Sampah-sampah yang dihasilkan dari aktivitas manusiapun semakin banyak seperti sampah hasil-hasil produksi sampai limbah zat kimia. Manusia dimanapun berada membutuhkan tempat tinggal, karena tempat tinggal merupakan status lembaga sosial (Keman, 2005). Setiap manusia yang tinggal di suatu daerah tidak akan lepas dari aktivitas membuang sampah.

Sampah dilihat dari sudut pandang ekonomi merupakan denda yang sudah hilang nilainya dan memiliki efek negatif terhadap pencemaran lingkungan (Sofyan, 2013). Sampah yang di hasilkan dari aktivitas manusia memberikan dampak negatif bagi lingkungan. Sampah dapat mempengaruhi kesehatan manusia jika tidak dikelola secara benar, maka dibutuhkan adanya pengaturan terhadap pengelolaannya. Aktivitas pembuangan sampah yang tidak sesuai prosedur kesehatan yang telah ditetapkan dapat menjadi sumber pencemaran udara, sumber pencemaran pemukiman, menjadi tempat hidup kuman dan tempat berkembang biak serta sarang dari binatang pengerat dan serangga, sehingga dapat membahayakan bagi kesehatan ( Mubarak \& Chayatin, 2009).

Pengelolaan sampah pada suatu daerah bertujuan untuk membantu masyarakat setempat terhadap sampah yang dihasilkannya untuk menciptakan lingkungan yang bersih, sehat dan baik serta memelihara kesehatan masyarakat. Pengumpulan sampah menjadi tanggungjawab setiap rumah tangga. Setiap rumah tangga harus memiliki tempat khusus untuk mengumpulkan sampah atau yang sering disebut juga sebagai bank sampah. Masing-masing bank sampah tersebut harus diangkut ke lokasi pembuangan sampah sementara, sesudah itu dilanjutkan ke Tempat Pembuangan Akhir sampah (TPA) (Notoatmodjo, 1997).

Model pengelolahan sampah di Indonesia memiliki dua metode yaitu sistem urugan dan sistem tumpukan. Pengelolaan sampah pertama adalah sistem urugan yaitu sampah yang dibuang di cekungan atau lembah tanpa diberikan perlakuan. Urugan bisa dilakukan di lokasi yang tepat, yaitu jika tidak ada permukiman warga dibawahnya, sehingga tidak menimbulkan polusi-polusi seperti: polusi udara, polusi pada air sungai, longsor, atau estetika. Model ini umumnya dilakukan untuk suatu kota yang volume sampahnya tidak terlalu besar.

Pengelolaan sampah kedua yaitu kelanjutan dari sistem urugan. Model ini dapat dilakukan secara komprehensif, sebenarnya sama dengan teknologi aerobic. Hanya saja tumpukan perlu dilengkapi dengan unit saluran air buangan, pengolahan air buangan (leachate), dan pembakaran ekses gas metan (flare). Model ini sudah memenuhi persyaratan kesehatan pada lingkungan. Model tumpukan ini umumnya tidak lengkap, karena tergantung dari kondisi ekonomi keuangan serta kepedulian pejabat daerah setempat akan kesehatan lingkungan. Model seperti ini sudah banyak di terapkan di kota-kota besar (Soemirat, 2011).

Menurut Soemirat (2011) proses pembuangan sampah semestinya menghasilkan pencemaran berupa leachate. Kandungan leachate sendiri bergantung pada kualitas sampah, sehingga di dalam leachate terdapat mikroba pathogen, logam zat besi dan zat-zat lainnya yang berbahaya. Dampak dari pencemaran sampah yaitu pencemaran bau di udara, dampaknya aroma kurang sedap yang di hasilkan dari sampah-sampah yang menumpuk, hal ini membuat tidak nyaman warga sekitar. Dampak dari pembuangan sampah juga dapat berakibat pencemaran tanah yang 
berdampak pada tercemarnya air bersih akibat dari zat-zat kimia yang tercamput di dalam tanah.

Salah satu Tempat Pembuangan Akhir (TPA) yang berkembang di Kota Malang adalah TPA Talangung kecamatan Kepanjen. TPA Talangung berdiri sejek tahun 2009 dan di resmikan secara langsung oleh gubernur Jawa Timur yaitu Bapak Dr. H Soekarwo pada tanggal 17 Desember 2011 seluas 2 Hektar menerima sekitar 87 TPS yang tersebar di Sembilan kecamatan di kabupaten Malang. Sampai saat ini sekitar 10 ton sampah yang datang ke TPA Talanggung, hal ini tidak menutup kemungkinan berdampak bagi kesehatan masyarakat sekitar yang tinggal di daerah TPA.

Hasil observasi awal dengan wawancara yang dilakukan kepada salah satu pengelola TPA di Talangagung ada permasalahan terkait bertambahnya sampah setiap tahunnya, dimungkinkan sampah akan overload jika tidak titangani dengan cepat. Pengelolaan sampah di TPA Talangagung memberikan efek negatif bagi beberapa warga di sekitar TPA. Mayoritas warga berusia 30 tahun ke atas mengalami gangguan kesehatan berupa gatal-gatal dan batuk terus-menerus.

Berdasarkan wawancara dengan pengelola TPA pencemaran udara tidak begitu berpengaruh terhadap warga sekitar. Di TPA Talanggung sendiri hal tersebut jarang terjadi, dalam pengelolaan sampah sesuai dengan prosedur yang di terapkan pemerintah, sehingga tanah tidak tercemari oleh zat-zat berbahaya yang di bawa oleh sampah. Bau yang di timbulkan oleh sampah sangat minim dengan jarak 50 meter bau sampah sudah tidak tercium. Hal ini tetap tidak baik bagi masyarakat yang setiap hari bergelut dengan sampah tanpa disadari dampak dari sampah akan mengganggu kesehatam masyarakat itu sendiri.

Penelitian ini bertujuan untuk mengetahui aktivitas-aktivitas masyarakat dan mengetahui dampak keberadaan TPA Talangagung Kabupaten Malang terhadap resiko gangguan kesehatan warga disekitar TPA Talangagung. Selain itu, juga untuk memberikan edukasi terhadap masyarakat agar selalu safety dalam melakukan pekerjaan di sekitar TPA tersebut. Dari penelitian ini dapat diketahui dampak dari TPA bagi masyarakat, agar masyarakat dapat termotivasi dan berpartisipasi dalam mencegah dampat negatif dari sampah terhadap kesehatan masyarakat sekitar TPA Talangagung sendiri.

\section{METODE}

Penelitian ini di laksanakan di Tempat Pembuangan Akhir Sampah (TPA) desa Talangagung Kepanjen yang bersifat observasional, jenis penelitian yang digunankan pada penelitian ini yaitu deskriptif kuantitatif dengan menggambarkan resiko yang di alami masyarakat sekitar TPA menggunakan data yang telah didapatkan.

Data informan dan narasumber diambil dengan memakai teknik simple random sampling karena berdasarkan pengetahuan dan pengalaman peneliti yang ada, belum ada suatu prosedur penarikan sampel tandingan yang lebih efisien daripada simple random sampling, selain itu terbatasnya pengetahuan terhadap unsusr-unsur populasi. Analisis data yang dilakukan dengan menggunakan rumus presentase yang disajikan dalam bentuk tabel, dari populasi masyarakat yang ada hanya diambil beberapa sampel secara acak. Sampel dari penelitian ini yaitu para masyarakat sekaligus pekerja yang berada di TPA Talangagung Kabupaten Malang. Dengan cara membagikan instrumen yang telah disediakan kepada responden.

Instrumen yang digunakan dalam penelitian ini adalah kuesioner dan checklist. Penyusunan instrumen variabel yang digunakan sebagai acuan yaitu tentang kondisi 
kesehatan masyarakat setempat, serta lingkungan sekitar TPA Talangagung yang mereka tempati sehari-hari sebagai mata pencaharian ataupun tempat mukim warga setempat. Indikator gangguan kesehatan diukur dari resiko gejala-gejala gangguan kesehatan yang dirasakan responden, berdasarkan data hasil penelitian gangguan kesehatan yang dialami. Data di analisis menggunakan rumus persentase sebagai berikut.

$$
\begin{aligned}
& \text { Rumus presentase: } P=\frac{F}{N} \mathrm{X} \\
& 100
\end{aligned}
$$

\section{Keterangan}

$\mathrm{P}=$ presentase jawaban

$\mathrm{F}=$ presentase nilai yang diperoleh dari seluruh item

$\mathrm{N}=$ jumlah responden

$100 \%$ = bilangan tetap

\section{HASIL DAN PEMBAHASAN \\ Hasil}

Hasil penelitian menunjukkan bahwa ada responden yang mengalami gangguan kesehatan, akan tetapi gangguang kesehatan yang mereka alami berbeda-beda. Gejala gangguan kesehatan yang paling banyak dialami oleh responden yaitu gangguan kesehatan sistem pernafasan, seperti yang ditunjukkan pada table berikut ini.

Tabel.1 Distribusi Responden Berdasarkan Jenis Gejala Gangguan Kesehatan di TPA Talangagung Kepanjen.

\begin{tabular}{cc}
\hline Gangguan Kesehatan & Persentase \\
\hline Sistem Pernafasan & $40 \%$ \\
Sistem Pencernaan & $10 \%$ \\
Penyakit Kulit & $20 \%$ \\
Tidak ada gangguan & $30 \%$ \\
\hline
\end{tabular}

Hasil penelitian ini juga menunjukkan ada beberapa responden mengalami beberapa gangguan kesehatan. Hasil dari data tersebut menunjukkan bahwa $40 \%$ responden yang mengalami gangguan sistem pernafasan mulai dari nyeri dada dan sesak nafas. Gangguan penyakit kulit sebersar $20 \%$ responden. Gejala yang paling sedikit dialami oleh responden adalah gangguan pada sistem pencernaan terhitung hanya sebanyak $10 \%$.

\section{Pembahasan}

Peraturan Pemerintah tentang syarat lokasi TPA diatur dalam Peraturan Pemerintah Nomor 81 tahun 201 (Republik Indonesia 2012). Peraturan Pemerintah Nomor 81 tahun 2012 lokasi TPA paling sedikit harus memenuhi syarat, yaitu : a) Geologi, kondisi geologi yang dimaksud adalah kondisi yang tidak berada di daerah patahan atau sesar yang masih aktif, tidak berada pada zona bahaya geologi misalnya daerah gunung berapi, tidak berada di daerah berlahan gambut, tidak berada didaerah karst. b) Hidrogeologi, maksud dari hidrogeologi yaitu kondisi muka air tanah yang kurang dari 3 meter, kondisi kelulusan tanah tidak lebih besar dari 10-6 cm/detik, dan jarak tehadap sumber air minum lebih besar dari 100 meter di hilir aliran. c) Kemiringan 
zona, yang dimaksud dengan kemiringan zona yaitu kemiringan lokasi TPA berada pada kemiringan kurang 20\%. d) Tidak berada dikawasan lindung atau cagar alam.

Penempatan lokasi TPA harus mengacu Standar Nasional Indonesia (SNI) nomor 03-3241-1994 tentang tata cara pemilihan lokasi TPA yang harus dilalui (Irawan \& Yudoyono, 2014). Perencanaan daerah TPA harus ditempatkan jauh dari lokasi pemukiman penduduk, dihindarkan jalan sempit yang kiri-kanannya adalah permukiman penduduk karena bau yang dihasilkan akan langsung terjebak di kamar-kamar penduduk, batas aman yang tidak boleh dibuat pemukiman selebar $100 \mathrm{~m}$ kiri-kanan jalan, TPA sebaiknya mengarah ke hilir tidak terlalu dekat dengan pantai agar tidak tercemar perairannya (Sudradjat, 2009). Lokasi tempat tinggal masyarakat dari TPA berjarak sekitar 500 meter.

Metode dan tahap-tahap yang dilakukan dalam pengelolaan sampah diantaranya sebagai berikut. a) Metode sanitary landfill (lahan urug saniter), yaitu pemusnahan sampah dengan cara membuat lubang di tanah kemudian sampah dimasukkan dan di timbun dengan tanah sebagai lapisan penutup lalu dipadatkan, cara ini memerlukan tempat yang luas dengan tanah yang bisa menimbunnya dan juga alat-alat besar. b) Inceneration (dibakar), yaitu memusnahkan sampah dengan jalan membakar di dalam tungku yang digunakan khusus untuk pembakaran, metode ini bermanfaat untuk memperkecil volume sampah sampai satu per tiga dan juga tidak memerlukan ruang yang luas. Panas yang dihasilkan dari pembakaran ini juga dapat digunakan sebagai sumber uap dan pengelolaan dapat dilakukan secara terpusat dengan jadwal jam kerja. Akan tetapi penerapan dengan menggunakan metode ini memerlukan biaya yang besar, lokasi pembuangan pabrik juga sulit didapat karena keberadaan penduduk, dan peralatan-peralatan yang digunakan dalam incenerasi. c) Composting (dijadikan pupuk), yaitu mengelola sampah menjadi pupuk kompos, composting ini khusus digunakan untuk sampah organik (Mubarak \& Chayatin, 2009).

Pengelolan sampah yang diterapkan di TPA Talangagung menggunakan sistem sanitary landfill (lahan urug saniter) akan tetapi di TPA Talangagung penutupan pada sistem sanitary landfill-nya di tutup menggunakan sejenis plastik kemudian pada penutupan terakhir baru menggunakan tanah yang kemudian dipadatkan. Alasan penggunaan plastik sebagai penutup yaitu agar suhu di dalam lebih panas karena celah pada tanah tertutup dengan rapat, sehingga memudahkan pembusukan pada sampah. Pengelolaan sampah di TPA Talangagung yaitu mengunakan metode tumpukan di lengkapi saluran pembuangan (leachate), dan pembakaran ekses gas metan. Penutup sampah di TPA Talangagung menggunkan terpal agar sampah mudah membusuk dan mengeluarkan gas metan tersebut.

Secara garis besar di TPA Talangagung tempat pembuangan sampah yang ramah lingkungan, karena proses pengolahannya telah sesuai dengan standarisasi. TPA di Talanganggung dapat dijadikan contoh untuk TPA lainnya. Secara teoritis gangguan kesehatan yang dialami masyarakat di sekitar TPA pada umumnya karena dampak dari paparan gas hasil dekomposisi sampah terhadap manusia tergantung dari beberapa faktor, diantaranya yaitu lamanya seseorang berada dilingkungan paparan. Seberapa sering seseorang terpapar, besarnya konsentrasi gas dan daya tahan seseorang terhadap paparan tersebut (Singga, 2014).

Hasil penelitian menunjukkan bahwa adanya Tempat Pembuangan Akhir di desa Talangagung Kepanjen memberikan resiko bagi gangguan kesehatan masyarakat di sekitar Tempat Pembuangan Akhir, seperti yang terlihat pada tabel resiko gangguan kesehatan terbesar hanya $40 \%$ berupa ganguan pernafasan. Penyakit pernafasan seperti 
batuk yang dialami oleh warga yang bekerja di TPA terutama ibu atau bapak yang sudah lanjut usia rentan. Mereka bekerja memilah sampah tanpa mengunakan seperti masker dan sarung tangan sehingga ibu-ibu atau bapak-bapak yang sudah lanjut usia bekerja di TPA kadang terinfeksi batuk. Ada hubungan antara lama bekerja dengan keluhan gangguan pernafasan, menurut Morgan dan Parkes (Budiono, 2007), waktu yang dibutuhkan seseorang yang terpapar kontaminan pencemar udara untuk terjadinya gangguan fungsi paru yaitu kurang lebih 10 tahun. Hal ini juga sesuai dengan hasil wawancara yang diperoleh, menyebutkan bahwa masyarakat yang bekerja di sekitar TPA sebagian besar mengalami keluhan gangguan pernafasan. Menurut Arthur, Guyton, dan Hall (2008) faktor keluhan gangguan pernafasan juga ada hubungannnya dengan jenis kelamin, karena secara anatomi sudah berbeda. Kapasitas dan volume seluruh paru pada wanita kuang lebih $20 \%$ hingga $25 \%$ lebih kecil dibandingkan laki-laki.

Lokasi TPA yang jauh perilaku masyarakat juga mempengaruhi kualitas kesehatan masyarakat (Puspita, et al., 2016). Data penderita penyakit kulit sebesar $20 \%$ dari responden. Penyakit kulit yang diderita masyarakat contohnya gatal-gatal pada kulit. Gatalgalat terjadi karena kurang menjaga kebersihan lingkungan, bukan disebabkan oleh air sumur yang tercemar limbah TPA. Sumur warga dengan TPA cukup jauh sehingga tergolong aman, karena air yang masyarakat gunakan tidak tercampuri oleh limbah yang ada di TPA.

Lokasi TPA dan pengolahan sampah yang kurang maksimal menjadi tempat yang nyaman bagi banyak organisme dan bagi berbagai binatang seperti lalat, dan anjing yang dapat menjangkitkan penyakit diare, kolera, tifus karena virus yang berasal dari sampah dengan pengolahan tidak tepat ( Ayen, et al., 2016). Masyarakat yang menderita penyakit pencernaan sebesar 10\%. Ganguan pencernaan dapat disebabkan oleh hewan-hewan yang menghinggapi makanan. Ganguan pencernaan bukan diakibatkan dari hewan-hewan yang berasal dari TPA. Di TPA jarang ditemui serangga seperi lalat, nyamuk, dan kecoa. Hal ini disebabkan karena pengolahan sampah di TPA sudah baik dan memenuhi standa. Masyarakat yang bekerja di sekitar TPA juga menjaga kebersihan makanan yang mereka bawa dari rumah sebagai bekal di tempat kerja yang berada di sekitar TPA, sehingga hal tersebut meminimalisir terjadinya gangguan sistem pencernaan yang disebabkan oleh bakteri-bakteri yang ada disekitar TPA.

\section{KESIMPULAN}

Masyarakat sekitar TPA mengalami ganguaan pernafasan sebesar 40\%, 20\% gangguan pencernaan dan $10 \%$ gangguan kulit. Ganguan kesehatan yang dialami oleh masyarakat bukan disebabkan oleh pengelolaan TPA Talangagung. Disarankan kepada masyarakat sekitar TPA Talangagung Kabupaten Malang terutama yang sehari-harinya bekerja di TPA tersebut, supaya memakai pelindung diri pada saat jam kerja untuk lebih memninimalisir resiko gangguan-gangguan kesehatan yang ada, seperti menggunakan masker.

\section{DAFTAR PUSTAKA}

Irawan, Agus Bambang \& Yudoyono, Andi Renata Ade. (2014). Studi Kelayakan Penentuan Pemrosesan Akhir Sampah (TPA) di Pulai Bintang Provinsi Kepulauan Riau. Jurnal Ilmu Lingkungan, 12 (1), 1-11.

Sofyan, Arief.(2013). Pengelolaan Sampah Malang Raya Menuju Pengelolaan Terpadu yang Berbasis Partisipasi Masyarakat. Jurnal Humanity. 8 (2), 195-208. 
Guyton, Arthur C \& Hall, Jhon E . (2008). Buku Ajar Fisiologi Kedokteran. Jakarta: EGC.

Ayen, Domitila, et al,. (2016). Gambaran Pengolahan Sampah dan Dampaknya Terhadap Kesehatan Masyarakat di Wilayah TPA Bantar Gebang Bekasi Tahun 2016. Jurnal Persada Husada Indonesia. 3(1), 59-71.

Sudradjat . (2009). Mengelola Sampah Kota. Jakarta: Penebar Swadaya.

Budiono. (2007). Risiko Gangguan Fungsi Pada Pekerja Pengecatan Mobil. Tesis. Universitas Diponegoro, Indonesia.

Puspita, et al.,. (2016). Pengaruh Perilaku Masyarakat yang Bermukim di Kawasan Bantaran Sungai Karang Anyar Kota Tarakan. Jurnal Manusia dan Lingkungan. 23(2), 249-258

Soemirat, Juli. (2011). Kesehatan Lingkungan. Yogyakarta: Gadjah Mada University Press.

Republik Indonesia. (2012.) Peraturan Pemerintah Republik Indonesia Nomor 81 Tahun 2012 Tentang Pengelolaan Sampah Rumah Tangga Dan Sampah Sejenis Sampah Rumah Tangga. Jakarta.

Singga, Siprianus. (2014). Gangguan Kesehatan Pada Pemulung di TPA Alak Kota Kupang. Jurnal MKMI. 10 (1), 30-35.

Keman, Soedjajadi. (2005). Kesehatan Perumahan dan Lingkungan Pemukiman. Jurnal Kesehatan Lingkungan. 2(1), 29-42.

Notoatmodjo, Soekidjo. (1997). Ilmu Kesehatan Masyarakat Prinsip-Prinsip Dasar. Jakarta: Rineka Cipta.

Mubarak, et al,. (2009). Ilmu Kesehatan Masyarakat. Jakarta: Salemba Medika. 